\title{
Risk Management of Cyanotoxins in Singapore
}

\author{
Mong Hoo Lim', Hui Shi Melissa Tay', Denise A. Devotta', \\ Maxine A. D. Mowe2 ${ }^{2}$ Simon M. Mitrovic ${ }^{2,3}$ \\ ${ }^{1}$ Water Quality Department, Public Utilities Board (PUB), Singapore \\ ${ }^{2}$ Freshwater and Invasion Biology Laboratory, Department of Biological Science, National University of Singapore (NUS), Singapore \\ ${ }^{3}$ Freshwater and Estuarine Research Group, School of Life Sciences, University of Technology Sydney, Sydney, Australia \\ Email:lim_mong_hoo@pub.gov.sg
}

How to cite this paper: Lim, M.H., Tay, H.S.M., Devotta, D.A., Mowe, M.A.D. and Mitrovic, S.M. (2020) Risk Management of Cyanotoxins in Singapore. Journal of Water Resource and Protection, 12, 512-525. https://doi.org/10.4236/jwarp.2020.126031

Received: April 9, 2020

Accepted: June 26, 2020

Published: June 29, 2020

Copyright () 2020 by author(s) and Scientific Research Publishing Inc. This work is licensed under the Creative Commons Attribution-NonCommercial International License (CC BY-NC 4.0). http://creativecommons.org/licenses/by-nc/4.0/ (c) (i) (5) Open Access

\begin{abstract}
Cyanotoxins produced by cyanobacteria pose significant challenges to water resource management due to the potential impacts they have on human health. Cylindrospermopsin (CYN) and microcystins (MC) are the more commonly detected cyanotoxins in Singapore's reservoirs. Among the MC congeners monitored locally, the most frequently detected variants are MC-RR (37.6\%), followed by MC-LR (25.6\%). MC-LA and MC-YR are the least frequently detected variants (7.1\%). No cyanotoxins have been detected in Singapore's treated drinking water. Singapore's National Water Agency (PUB) and the National Environment Agency (NEA) developed recreational water quality guidelines using $\mathrm{Chl} a$ concentrations of $50 \mu \mathrm{g} / \mathrm{L}$. In local surface waters, long-term data showed that at $50 \mu \mathrm{g} / \mathrm{L}$ of Chl a, MC-LR concentrations ranged from $<0.025 \mu \mathrm{g} / \mathrm{L}$ to $1 \mu \mathrm{g} / \mathrm{L}$. In addition to using Chl a concentrations, Microcystis cell counts in reservoir water have also been used to manage cyanotoxin risk in drinking water. Specifically, routinely monitored data from all 17 Singapore reservoirs indicated that to keep MC-LR concentrations below the WHO provisional guideline of $1 \mu \mathrm{g} / \mathrm{L}$ in drinking water, Microcystis cell counts needed to be $<10,000$ cells/ml. Culture experiments using local Microcystis isolates showed $M$. aeruginosa produced the most MC compared to $M$. ichthyoblabe, M. flos-aquae, and M. viridis. Based on the maximum toxin cell quota equivalent to the WHO provisional guideline for MC-LR of $1 \mu \mathrm{g} / \mathrm{L}$ in drinking water, a 5000 cells/ml cell count guideline was derived for $M$. aeruginosa. This cell count has also been incorporated into Singapore's cyanotoxin risk management framework for reservoirs.
\end{abstract}

\section{Keywords}

Chlorophyll-a, Cyanobacteria, Cyanotoxins, Nutrients, Tropical 


\section{Introduction}

The excessive production of cyanotoxins, produced by cyanobacteria, is increasingly recognised as a major challenge facing water resource management worldwide [1] [2]. Cyanobacteria are natural components of phytoplankton communities in freshwater systems. High water column stability allowing access to light, increased temperatures and nutrient enrichment (eutrophication) are some environmental conditions that can favour cyanobacterial proliferation (i.e. algal blooms) [2] [3]. Cyanobacterial blooms can lead to the excessive production of secondary metabolites, including taste and odour compounds (2-Methylisoborneol (2-MIB) and Geosmin) and cyanotoxins. High cyanotoxin loads from blooms have been linked to human and animal illness and death in over 50 countries [1]. Human exposure to cyanotoxins can occur through skin contact and ingestion or inhalation of water droplets during recreational activities [1] [4]. Commonly known cyanotoxins can be grouped according to their impacts on human health. For example, Microcystins (MC) are hepatotoxic, while Anatoxin-a (ATX) and Saxitoxin (STX) are neurotoxic. In contrast, the toxicity of Cylindrospermopsin (CYN) is non-organ specific [5]. As cyanobacterial blooms are increasing in frequency, severity, extent and duration on a global scale [3], it is beneficial to understand the strategies different countries are undertaking to manage the risks of bloom-associated cyanotoxin loads in freshwater systems.

Two of the most internationally recognized sets of guidance levels used to manage cyanotoxin risk in drinking water have been developed by the World Health Organisation (WHO) and the U.S. Environmental Protection Agency (USEPA). Of all the cyanotoxins, the WHO guideline focuses on MC because it is produced by Microcystis, the most common bloom-forming genus of cyanobacteria in freshwater [6]. MC is known to have $>80$ variants [7]. Among these, MC-LR is one of the most toxic and well-studied, and is therefore used as a surrogate for all other MC variants [7] [8]. The WHO provisional guideline for MC-LR in drinking water is $1.0 \mu \mathrm{g} / \mathrm{L}$. This MC-LR concentration is not expected to pose any significant risk to human health over a lifetime of exposure [9]. The USEPA 10-day Health Advisory (HA) value of MC in drinking water for bottle-fed infants and young children of pre-school age is $0.3 \mu \mathrm{g} / \mathrm{L}$, while that for school-age children through adults is $1.6 \mu \mathrm{g} / \mathrm{L}$. These HA values describe MC concentrations at or below which adverse health effects are not anticipated to occur over a 10-day duration of exposure [10]. Because adequate data on health effects are also available for CYN, the USEPA developed 10-day HA values for this cyanotoxin in drinking water; specifically $0.7 \mu \mathrm{g} / \mathrm{L}$ for bottle-fed infants and young children of pre-school age and $3 \mu \mathrm{g} / \mathrm{L}$ for school-age children through adults [10]. These USEPA and WHO guidelines form an important basis upon which individual countries develop their own locally-relevant standards.

At the national level, many countries have adapted the WHO guidance values on cyanotoxin concentrations to local conditions by using cyanobacterial biomass as a surrogate for cyanotoxin load [11]. Specifically, local cyanobacterial 
biomass levels that correspond to the cyanotoxin concentration specified in the WHO guidance value are incorporated into a series of alert levels of increasing severity. Commonly used parameters indicative of cyanobacterial biomass include phytoplankton cell numbers, biovolume or pigment concentrations (e.g. chlorophyll-a ( $\mathrm{Chl}$ a) or other cyanobacterial pigments detected by fluorometry) [11]. In most national frameworks, breaching any alert level of cyanobacterial biomass triggers a set of pre-defined responses or intervention plans aimed at reducing direct human exposure to the increasing cyanotoxin load. Measures aimed at reducing cyanotoxin load in source waters can ultimately help reduce cyanotoxin levels in drinking water (i.e. end product) as well [12]. Thus, understanding frameworks used to manage cyanotoxin risk management in raw water sources helps inform cyanotoxin risk management in drinking water supplies.

Cyanotoxin production and associated cyanobacterial ecology and growth have been extensively documented in temperate regions, but similar information from tropical regions is lacking [13] [14]. The differing climate and ecological conditions in temperate and tropical regions can give rise to distinct cyanobacterial bloom and associated cyanotoxin production dynamics. Because cyanobacterial blooms typically occur during periods of higher water temperatures and access to light [2] [3], seasonal transitions in temperate regions allow for prediction of bloom occurrence [15]. Existence of a bloom season enables pre-emptive measures to be enacted before the season to mitigate subsequent bloom occurrence. In contrast, high temperatures and light conditions usually characterise tropical regions year-round [13]. Consequently, cyanobacterial blooms can occur at any time of the year and last for an extended period of time [16] [17]. In this article, we discuss the risk management framework pertaining to cyanotoxins in tropical Singapore fresh water bodies with respect to the relationship between $\mathrm{Chl} a$ and $\mathrm{MC}$ concentrations, and the approach we use to manage cyanotoxin levels in source water to safeguard drinking water safety. Specifically, we present cyanobacterial biomass, cyanotoxins and water quality data collected from 17 reservoirs in Singapore over approximately seven years.

\section{Field Studies and Investigations Regarding the Prevalence of Cyanotoxins in Singapore}

Singapore is an island located at the tip of peninsular Malaysia $\left(1^{\circ} \mathrm{N}\right.$ of the equator). It has an average population density of 7953 inhabitants $/ \mathrm{km}^{2}$ [18] and is characterised by a tropical climate with Northeast and Southwest monsoons and inter-monsoon periods. Temperatures vary little year-round, ranging from $23^{\circ} \mathrm{C}$ to $33^{\circ} \mathrm{C}$ and long-term (1981 to 2010 ) mean annual rainfall total is 2166 $\mathrm{mm}$ [19]. The 17 freshwater reservoirs examined in this article have a range of surface areas $\left(0.59-7.47 \mathrm{~km}^{2}\right)$, average depths $(2-22 \mathrm{~m})$, and water residence times (12 - 1706 days). Catchment land cover for all reservoirs includes forested, agricultural and urban areas. All 17 reservoirs comprise an important compo- 
nent of the nation's potable water supply and some are also used for recreation. Local phytoplankton communities in the reservoirs are dominated by cyanobacteria. Some of the commonly detected genera include Cylindrospermopsis, Microcystis, Pseudanabaena, Planktolynbya, Chroococcales, Limnothrix and Oscillatoria, with occasional detections of Anabaena and Aphanizomenon.

Data presented in this article come from PUB's routine monitoring and a PUB-funded study as summarised below. A complete description of the methods used to analyse the water and phytoplankton samples from the studies can be found in the Appendix.

1) Routine monitoring carried out by PUB: Water samples from all 17 reservoirs were routinely collected on a monthly basis from January 2012 to February 2019, and analysed for Chl $a$ and cyanotoxins concentrations (MC-LR, MC-RR, MC-YR, MC-LA, CYN, ATX and STX). Microscopy was used to obtain phytoplankton cell counts.

2) PUB-funded study to determine:

a) Phytoplankton species capable of producing MC: Phytoplankton cells were separated from reservoir water samples, isolates from Microcystis and Planktothrix spp. were experimentally cultured and cyanotoxins analyses were run on the isolates to determine those capable of producing MC. DNA was also extracted from the cultured isolates and gene targeting was carried out to determine the prevalence of the MC-producing gene $(\mathrm{mcyD})$ in the isolates [20].

b) Relative toxin production from five Microcystis isolates: Five isolates of Microcystis known to produce MC-LR and MC-RR were cultured under varying temperatures. Cell count and toxin production under these varying temperatures $\left(27^{\circ} \mathrm{C}, 30^{\circ} \mathrm{C}, 33^{\circ} \mathrm{C}\right.$ and $\left.36^{\circ} \mathrm{C}\right)$ were measured. Part of these results has been published [21].

\subsection{Algae Biomass and Concentrations of Cyanotoxins}

From January 2012 to February 2019, Chl a concentrations ranged from $1.7 \mu \mathrm{g} / \mathrm{L}$ to $284.3 \mu \mathrm{g} / \mathrm{L}$, with average $\mathrm{Chl}$ a concentrations of $44.2 \mu \mathrm{g} / \mathrm{L}$. Phytoplankton cell counts ranged from 180 cells $/ \mathrm{ml}$ to $3,512,106$ cells $/ \mathrm{ml}$. Of all the cyanotoxins monitored, CYN was the most abundant (median concentration of $0.920 \mu \mathrm{g} / \mathrm{L}$; Table 1). This was almost seven times higher than the median concentration of MC-LR $(0.13 \mu \mathrm{g} / \mathrm{L})$, the next most abundant cyanotoxins detected. Similarly, CYN was also the most commonly detected cyanotoxin in Singapore's reservoirs, occurring in $>50 \%$ of all samples. MC-RR was the next most commonly detected toxin, occurring in $37.6 \%$ of samples (Table 1 ).

Among the $\mathrm{MC}$ congeners monitored, the most frequently detected $\mathrm{MC}$ variant was MC-RR (37.6\%), followed by MC-LR (25.6\%). MC-LA and MC-YR were the least frequently detected variants; both only occurred in $7.1 \%$ of all samples (Table 1). Concentration ranges and median values of the MC variants followed a similar pattern. In Singapore's freshwater systems, MC-RR and 
Table 1. Cyanotoxin concentrations from 17 Singapore reservoirs.

\begin{tabular}{cccccc}
\hline $\begin{array}{c}\text { Cyanotoxin (free and } \\
\text { cellbound forms) }\end{array}$ & Year & $\begin{array}{c}\text { Range } \\
(\mu \mathrm{g} / \mathrm{L})\end{array}$ & $\begin{array}{c}\text { Median } \\
(\mu \mathrm{g} / \mathrm{L})\end{array}$ & $\begin{array}{c}9^{\text {th }} \text { Percentile } \\
(\mu \mathrm{g} / \mathrm{L})\end{array}$ & $\begin{array}{c}\text { Occurrence } \\
(\% \text { samples detected) }\end{array}$ \\
\hline Microcystin-LR & Jan.-12 & $<0.025-8.89$ & 0.130 & 1.87 & 25.6 \\
Microcystin-RR & Jan.-12 & $<0.025-22.8$ & 0.129 & 6.57 & 37.6 \\
Microcystin-LA & Jan.-12 & $<0.025-0.272$ & 0.068 & 0.14 & 7.10 \\
Microcystin-YR & Jan.-12 & $<0.025-2.14$ & 0.099 & 0.51 & 7.10 \\
Cylindrospermopsin & Jan.-12 & $<0.100-12.5$ & 0.920 & 2.95 & 51.5 \\
Anatoxin-a & Jan.-12 & $<0.100$ & $<0.100$ & $<0.100$ & 0 \\
Saxitoxin & Feb.-17 & $<0.020-0.130$ & 0.032 & 0.120 & 1.80 \\
\hline
\end{tabular}

MC-LR concentrations were characterised by the largest ranges $(<0.025$ to 22.8 $\mu \mathrm{g} / \mathrm{l}$ and $<0.025$ to $8.89 \mu \mathrm{g} / \mathrm{l}$, respectively) and median values $(0.129 \mu \mathrm{g} / \mathrm{l}$ and $0.130 \mu \mathrm{g} / \mathrm{l}$, respectively). MC-LA and MC-YR had smaller ranges $(<0.025$ to $0.272 \mu \mathrm{g} / \mathrm{l}$ and $<0.025$ to $2.14 \mu \mathrm{g} / \mathrm{l}$, respectively) and median values $(0.068 \mu \mathrm{g} / \mathrm{l}$ and $0.099 \mu \mathrm{g} / \mathrm{l}$, respectively; Table 1 ). None of the previously-mentioned cyanotoxins were detected in our treated (drinking) water.

\subsection{Toxin Production by Microcystis Isolates}

Results from the Microcystis culture experiments indicated that 16 out of $24 \mathrm{Mi}$ crocystis spp. isolates (Six M. ichthyoblabe, three M. panniformis, four M. aeruginosa, one $M$. flos-aquae and two $M$. viridis) produced $\mathrm{MC}$, while none of the Planktothrix spp. isolates produced any toxins [20]. Also, the MC-producing gene (mcyD) was found in 15 of the 21 Microcystis spp. isolates, indicating that a high percentage of the natural Microcystis populations in Singapore's reservoirs are capable of toxin production [20].

Culturing of the five Microcystis isolates demonstrated that M. aeruginosa produced the highest concentrations of MC. Mean and maximum MC cell concentrations of M. aeruginosa ( $136.6 \mathrm{fg} /$ cell and $196.3 \mathrm{fg} / \mathrm{cell}$ respectively) were over four times greater than mean and maximum MC cell concentrations from all the other four isolates combined $(21.7 \mathrm{fg} / \mathrm{cell}$ and $42.6 \mathrm{fg} / \mathrm{cell}$, respectively; Table 2). Assuming the maximum toxin production concentration (196.3 fg/cell), 5,095 M. aeruginosa cells per $\mathrm{mL}$ would produce the equivalent of $1 \mu \mathrm{g}$ of $\mathrm{MC}$ in $1 \mathrm{~L}$ of water (Table 2; [20]).

\section{Cyanotoxin Risk Management Approach in Singapore}

In Singapore, two government agencies are involved in cyanotoxin risk management; PUB, Singapore's National Water Agency and the National Environment Agency (NEA). PUB manages cyanotoxin risk across the nation's 17 reservoirs to ensure the safety of drinking and recreational water, while NEA is the regulatory agency that ensures PUB's compliance with local and international guidelines regarding water safety. The main framework PUB uses to manage 
Table 2. Cell count guidelines (cells/ml) from the research study (unpublished) based on World Health Organisation (WHO) drinking water $(\mathrm{MC}<1 \mu \mathrm{g} / \mathrm{L})$ and recreational water $(\mathrm{MC}<20 \mu \mathrm{g} / \mathrm{L})$ guidelines (WHO, 2003). Microcystis cell count guidelines are based on growth under laboratory conditions (Nitrogen: $14 \mathrm{mg} / \mathrm{L}$, Phosphorus: $1.2 \mathrm{mg} / \mathrm{L}, 27^{\circ} \mathrm{C}-28^{\circ} \mathrm{C}, 120 \mu \mathrm{mol} / \mathrm{m} / \mathrm{s}$, detailed methods are in Appendix).

\begin{tabular}{ccccccc}
\hline \multirow{2}{*}{ Microcystis strains } & Mean MC cell & Max MC cell & & \multicolumn{2}{c}{$\begin{array}{c}\text { Cell count guideline based on } \\
\text { mean MC cell quota (cells/ml) }\end{array}$} & \multicolumn{2}{c}{$\begin{array}{c}\text { Cell count guideline based on } \\
\text { max MC cell quota (cells/ml) }\end{array}$} \\
\cline { 5 - 8 } & quota (fg/cell) & quota (fg/cell) & $\begin{array}{c}\text { Drinking Water } \\
\text { guideline }\end{array}$ & $\begin{array}{c}\text { Recreational } \\
\text { water guideline }\end{array}$ & $\begin{array}{c}\text { Drinking Water } \\
\text { guideline }\end{array}$ & $\begin{array}{c}\text { Recreational } \\
\text { water guideline }\end{array}$ \\
\hline M. ichthyoblabe $(L P)$ & 0.9 & 1.3 & $1,111,111$ & $22,222,222$ & 234,678 & $15,265,660$ \\
M. icthyoblabe $(T G)$ & 2.1 & 4.3 & 476,190 & $9,523,810$ & 763,283 & $4,693,559$ \\
M. flos-aquae & 5.3 & 10.3 & 188,679 & $3,773,585$ & 97,292 & $1,945,835$ \\
M. aeruginosa & 136.3 & 196.3 & 7337 & 146,735 & 5095 & 101,897 \\
M. viridis & 13.4 & 26.7 & 74,627 & $1,492,537$ & 37,484 & 749,675 \\
\hline
\end{tabular}

cyanotoxin risk is the Water Safety Plan (WSP). Based on the concepts of the WHO's recommended Water Safety Plan [12], PUB's WSP lists contaminants of concern, control limits of these contaminants and corrective actions to be taken at each stage of the water loop to ensure water safety throughout the supply chain. One of the groups of contaminants monitored as part of the WSP is cyanotoxins produced by cyanobacterial blooms in the reservoirs, and the associated corrective actions involve catchment and reservoir management strategies to minimize bloom occurrence.

In 2007, PUB and NEA first used a risk-based assessment approach to establish recreational water quality guidelines. These guidelines consist of an alert level of Chl $a$ at which concentrations of cyanotoxins in local waters were likely to be a concern for human health. The function of these guidelines is to determine the suitability of fresh water bodies for primary contact activities (e.g. skiing and wakeboarding) where the whole body or face and trunk are frequently immersed or it is likely that some water will be swallowed. By using available Chl $a$ and cyanotoxin concentration data from the reservoirs, it was determined that $50 \mu \mathrm{g} / \mathrm{L}$ of Chl a corresponded to $<0.025$ to $1 \mu \mathrm{g} / \mathrm{L}$ of MC-LR. As a result, 50 $\mu \mathrm{g} / \mathrm{L}$ of Chl a was established as the level beyond which there would be a higher risk of cyanotoxin production in concentrations that could have moderate or severe human health impacts. PUB and NEA regularly review this recreational guideline value using routinely monitored data (Figure 1). Analyses of an expanded dataset that includes Chl $a$ and total MC (MC-LR, MC-RR, MC-LA and MC-YR) concentrations indicate that $95 \mu \mathrm{g} / \mathrm{L}$ and $220 \mu \mathrm{g} / \mathrm{L}$ of Chl a corresponded to $10 \mu \mathrm{g} / \mathrm{L}$ and $20 \mu \mathrm{g} / \mathrm{L}$ of total MC concentrations, respectively (Figure 2).

PUB in collaboration with NUS, used the total MC (MC-RR and MC-LR) cell quota data from the five cultured Microcystis strains [20] to develop Microcystis cell counts for PUB reservoir management strategies corresponding to the WHO provisional guideline for MC-LR of $1 \mu \mathrm{g} / \mathrm{L}$ in drinking water and WHO guideline for total $\mathrm{MC}$ of $<20 \mu \mathrm{g} / \mathrm{L}$ in recreational water [22] (Table 2). Both $M$. aeruginosa and $M$. viridis released at least two-fold higher concentrations of MC 


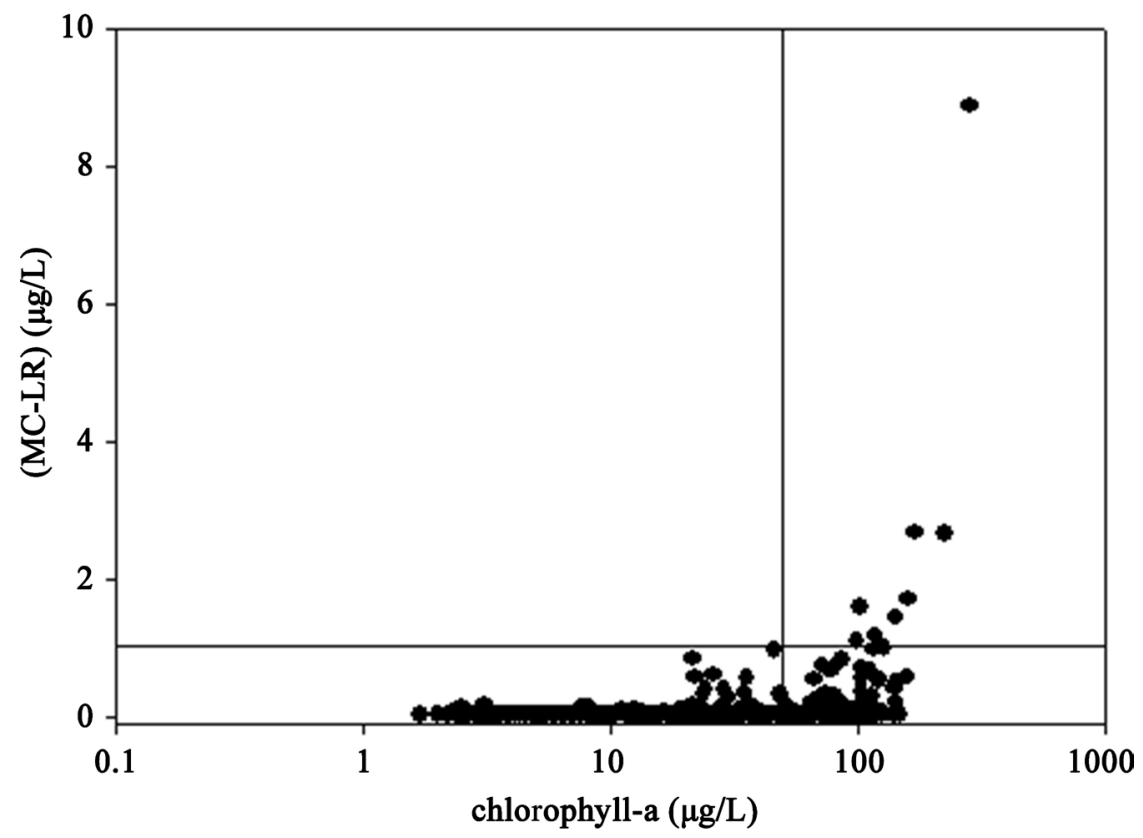

Figure 1. Scatterplot of microcystin-LR (MC-LR) (ug/L) and chlorophyll-a concentrations in 17 Singapore reservoirs.

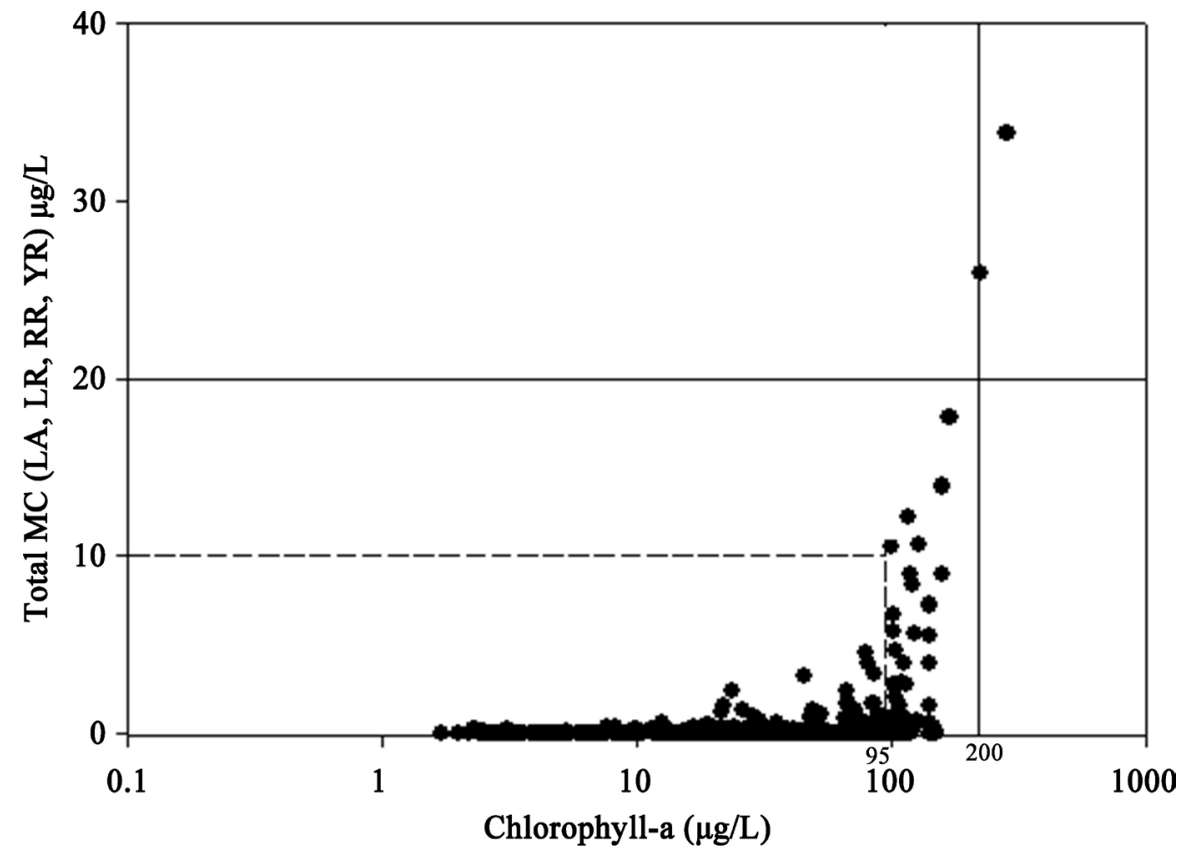

Figure 2. Scatterplot of total microcystins (MC-LA, MC-LR, MC-RR, MC-YR) and chlorophyll-a concentrations in 17 Singapore reservoirs.

actively or by cell lysis, as compared to $M$. icthyoblabe and $M$. flos-aquae (Table 2). Among the 5 strains studied, M. aeruginosa had the highest maximum MC cell quota per cell (196.3 fg/cell) which indicated $M$. aeruginosa was the highest MC producing isolate.

Microcystis cell counts used in Australian drinking water quality guidelines are similar to the Microcystis cell counts PUB uses. In Australia, the MC notifi- 
cation level (30\% of density equivalent to MC: $1.3 \mu \mathrm{g} / \mathrm{L}$ ) and MC alert level (1.3 $\mu \mathrm{g} / \mathrm{L}$ ) in drinking water are based on MC production from a toxic strain of $M$. aeruginosa. These notification and alert levels corresponded to 2000 and 6500 Microcystis cells/ml respectively [23]. The alert level guideline for $M$. aeruginosa from Australia (6500 cells $/ \mathrm{ml}$ ) is close to the mean MC cell quota drinking water cell count guideline for $M$. aeruginosa from Singapore ( $<7337$ cells/ml, Table 2$)$.

PUB further investigated the relationship between Microcystis cell counts and MC-LR concentrations from all 17 Singapore reservoirs. The data showed that Microcystis cell counts $<10,000$ cells/ml corresponded to MC-LR concentrations $<1 \mu \mathrm{g} / \mathrm{L}$; the provisional WHO guideline for drinking water (Figure 3). These data corroborate results presented in Table 2 that suggest keeping MC-LR concentrations below $1 \mu \mathrm{g} / \mathrm{L}$ necessitate keeping mean and maximum cell counts of the highly toxic $M$. aeruginosa below $7337 \mathrm{cells} / \mathrm{ml}$ and $5095 \mathrm{cells} / \mathrm{ml}$, respectively. In Table 2, the cell count guidelines based on the MC cell quotas for drinking water are lower than the levels of the recreational water guideline. To err on the conservative side, PUB selected the $M$. aeruginosa cell count guideline based on the maximum cell quota equivalent to the WHO drinking water guideline $(5095 \mathrm{cells} / \mathrm{ml})$. This cell count was then rounded down to $5000 \mathrm{cells} / \mathrm{ml}$ and used for cyanotoxin risk management of reservoirs in Singapore as shown in Table 3.

A key component of reducing cyanotoxin risk in urban reservoirs is nutrient control. Unlike ambient temperature and light conditions which are beyond practical control in waterways and reservoirs, the magnitude of nutrient loading into water bodies can be managed and thereby used to prevent or minimize

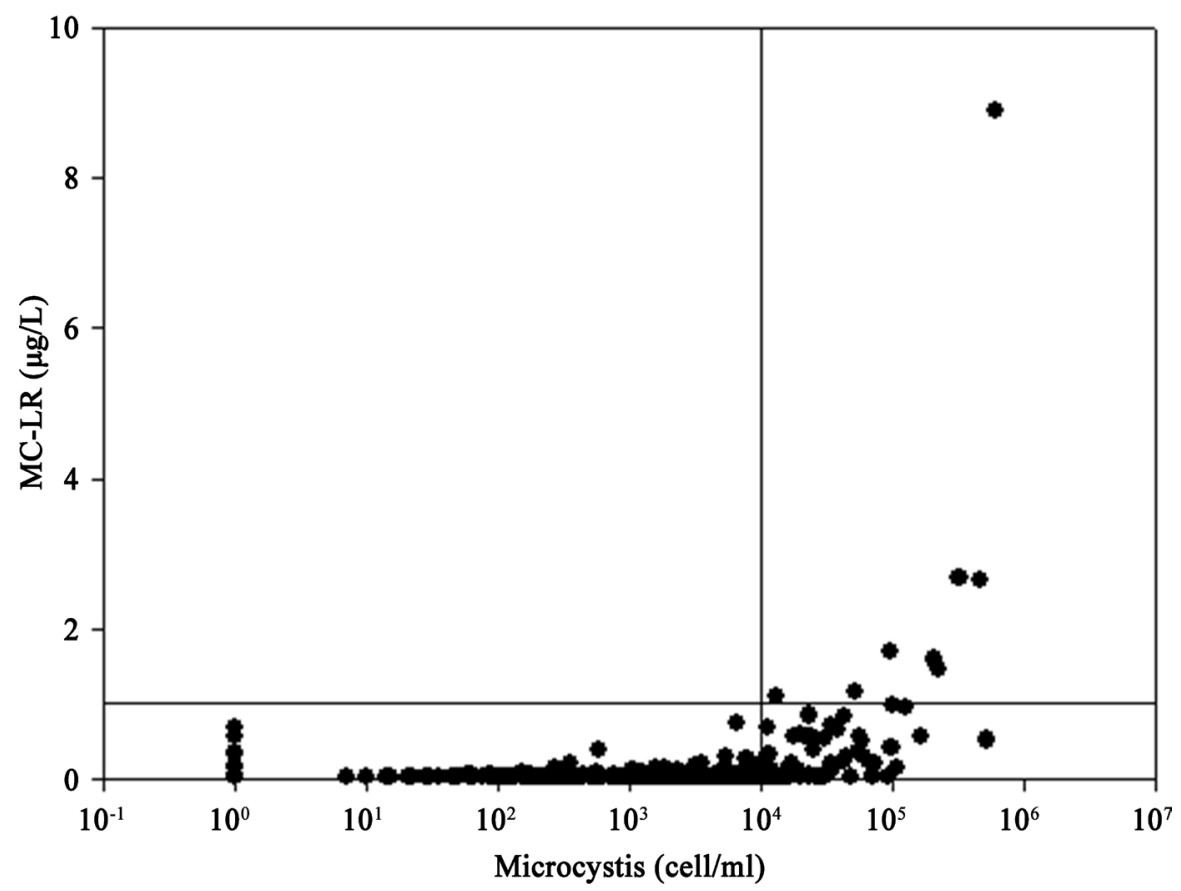

Figure 3. Scatterplot of microcystin-LR (MC-LR) concentrations and Microcystis cell counts in 17 Singapore reservoirs. 
Table 3. PUB cyanotoxin action plan adopted for management of cyanobacteria and toxins in Singapore reservoirs.

\begin{tabular}{|c|c|c|}
\hline Routine Operations & Trigger/action levels & Follow-up \\
\hline $\begin{array}{l}\text { Routine patrol at } \\
\text { reservoirs }\end{array}$ & Algal scums/blooms observed & $\begin{array}{l}\text { Collect samples for microscopic } \\
\text { examination, Chl a testing and toxin test; } \\
\text { physical removal of algal scums in water }\end{array}$ \\
\hline $\begin{array}{l}\text { Routine monitoring } \\
\text { of chlorophyll-a and } \\
\text { algae counts in } \\
\text { reservoirs }\end{array}$ & $\begin{array}{l}\text { Chl a exceeds } 50 \mu \mathrm{g} / \mathrm{L} \text { and } \\
\text { sample dominated by potential } \\
\text { toxin producing cyanobacteria, } \\
\text { or } \text { Microcystis count exceeds } \\
5000 \text { cells } / \mathrm{ml}\end{array}$ & $\begin{array}{l}\text { Conduct toxin analysis, management of } \\
\text { reservoir water quality by improving the } \\
\text { turnover (dilution with alternative source } \\
\text { of water and ensure there is no } \\
\text { de-stratification) }\end{array}$ \\
\hline $\begin{array}{l}\text { Routine monitoring } \\
\text { of toxins at reservoirs }\end{array}$ & $\begin{array}{l}\text { MC-LR in raw and treated water } \\
\text { exceed guideline level of } 1 \mu \mathrm{g} / \mathrm{L} \\
\text { for drinking water }\end{array}$ & $\begin{array}{l}\text { Increase toxin monitoring in source and } \\
\text { treated water, enhance the water treatment } \\
\text { process by introducing PAC or ozone. } \\
\text { Utilise alternative reservoir source supply. }\end{array}$ \\
\hline
\end{tabular}

cyanobacterial blooms. As part of an island-wide strategy to protect reservoir water quality, PUB works closely with other government agencies in Singapore to formulate land-use policies that require developments and industries, which are likely to pollute or discharge large quantities of nutrients to be located outside the reservoir water catchments. Another coordinated effort among PUB and other relevant government agencies has resulted in regulations specifying maximum nutrient concentrations in discharges entering waterways that NEA enforces. Across the island, there is also a clear separation between surface water drainage and sewage systems, hence minimizing the likelihood of nutrient loading into the reservoirs due to sewage contamination of surface water. Within reservoir catchments, PUB has adopted a number of nutrient control measures, including implementation of a sewer rehabilitation programme to minimise sewer leaks, growing of macrophytes at reservoir edges for nutrient uptake and suppression of algae growth, and promoting best management practices on farms and building green infrastructure to reduce nutrient loading from surface runoff. One specific example of this is the Active, Beautiful and Clean (ABC) Waters programme, which PUB launched in 2006. The ABC programme aims to detain storm water runoff on-site and improve runoff water quality via natural processes before the water flows into the reservoirs. To achieve this goal, ABC design features include rain gardens, bioswales and constructed wetlands. The $\mathrm{ABC}$ programme also has added communal benefits of providing recreational spaces for public use [24].

Long-term monitoring data have enabled PUB and NEA to have a better understanding of the dynamics of cyanotoxin production in Singapore's water bodies, and thereby developed locally-relevant guideline values to manage cyanotoxin risk in Singapore. Regular review and update of the cyanotoxin risk management plan and associated nutrient control measures are needed to cope with changing circumstances. This is especially important given the impacts climate change is having on the frequency, extent and duration of algae bloom occurrence. 


\section{Conclusion}

Understanding local environmental factors affecting the growth of cyanobacteria and cyanotoxin production is important for effective management of cyanotoxin risk. Chl a concentrations or phytoplankton cell counts can be used as indicators of potential risk to human health in recreational and drinking water resulting from cyanotoxins. In general, guideline values of parameters indicative of cyanobacterial biomass such as phytoplankton cell numbers, biovolume or pigment concentrations (e.g. chlorophyll-a ( $\mathrm{Chl} \mathrm{a}$ ) or other cyanobacterial pigments detected by fluorometry) can be developed on a national level and modified to account for site-specific conditions on a finer scale. These values can be used as effective operational tools for risk management of cyanotoxins in water. Regular review and update of the national cyanotoxin risk management plan and associated nutrient control measures are needed to ensure they remain relevant and effective, especially in the context of climate change.

\section{Acknowledgements}

The R \& D study was funded by PUB (Awarded to National University of Singapore, WBS grant number: R-154-000-523-490).

\section{Conflicts of Interest}

The authors declare no conflicts of interest regarding the publication of this paper.

\section{References}

[1] Loftin, K.A., Graham, J.L., Hillborn, E.D., Lehmann, S.C., Meyer, M.T., Dietze, J.E. and Griffith, C.B. (2016) Cyanotoxins in Inland Lakes of the United States: Occurrence and Potential Recreational Health Risks in the EPA National Lakes Assessment 2007. Harmful Algae, 56, 77-90. https://doi.org/10.1016/j.hal.2016.04.001

[2] Paerl, H.W. and Scott, J.T. (2010) Throwing Fuel on the Fire: Synergistic Effects of Excessive Nitrogen Inputs and Global Warming on Harmful Algal Blooms. Environmental Science \& Technology, 44, 7756-7758. https://doi.org/10.1021/es102665e

[3] Manning, S.R. and Nobles, D.R. (2017) Impact of Global Warming on Water Toxicity: Cyanotoxins. Current Opinion in Food Science, 18, 14-20.

https://doi.org/10.1016/j.cofs.2017.09.013

[4] Koreivienè, J., Anne, O., Kasperovičienè, J. and Burškyte, V. (2014) Cyanotoxin Management and Human Health Risk Mitigation in Recreational Waters. Environmental Monitoring and Assessments, 186, 4443-4459.

https://doi.org/10.1007/s10661-014-3710-0

[5] Yen, H., Lin, T. and Liao, P. (2011) Simultaneous Detection of Nine Cyanotoxins in drinking Water Using Dual Solid-Phase Extraction and Liquid Chromatography-Mass Spectrometry. Toxicon, 58, 209-218. https://doi.org/10.1016/j.toxicon.2011.06.003

[6] Yoo, R., Carmichael, W., Hoehn, R. and Hrudey, S. (1995) Cyanobacterial (BlueGreen Algal) Toxins: A Resource Guide. AWWA Research Foundation and American Water Works Association, Denver. 
[7] Dittmann, E., Fewer, D.P. and Neilan, B.A. (2012) Cyanobacterial Toxins: Biosynthetic Routes and Evolutionary Roots. FEMS Microbiology Reviews, 37, 23-43. https://doi.org/10.1111/j.1574-6976.2012.12000.x

[8] Shang, L., Feng, M., Liu, F., Xu, X., Ke, F., Chen, X. and Li, W. (2015) The Establishment of Preliminary Safety Threshold Values for Cyanobacteria Based on Periodic Variations in Different Microcystin Congeners in Lake Chaohu, China. Environmental Science Processes \& Impacts, 17, 728-739. https://doi.org/10.1039/C5EM00002E

[9] World Health Organization (2017) Guidelines for Drinking Water Quality. 4th Edition, Gutenberg.

[10] U.S. EPA (United States Environmental Protection Agency) (2015) Drinking Water Health Advisories for Two Cyanobacterial Toxins. EPA-820F15003.

https://www.epa.gov/sites/production/files/2017-06/documents/cyanotoxins-fact_s heet-2015.pdf

[11] Chorus, I. (2012) Current Approaches to Cyanotoxin Risk Assessment, Risk Management and Regulations in Different Countries. Federal Environment Agency (Umweltbundesamt). http://www.uba.de/uba-info-medien-e/4390.html

[12] Ibelings, B.W., Backer, L.C., Kardinaal, W.E. and Chorus, I. (2015) Current Approaches to Cyanotoxin Risk Assessment and Risk Management around the Globe. Harmful Algae, 49, 63-74. https://doi.org/10.1016/j.hal.2014.10.002

[13] Mowe, M.A.D, Mitrovic, S.M., Lim, R.P., Furey, A. and Yeo, D.C.J. (2015) Tropical Cyanobacterial Blooms: A Review of Prevalence, Problem Taxa, Toxins and Influencing Environmental Factors. Journal of Limnology, 74, 205-224.

https://doi.org/10.4081/jlimnol.2014.1005

[14] Cunha, D.G.F., Dodds, W.K. and Loiselle, S.A. (2018) Factors Related to Water Quality and Thresholds for Microcystin Concentrations in Subtropical Brazilian Reservoirs. Inland Waters, 8, 368-380. https://doi.org/10.1080/20442041.2018.1492526

[15] Mitrovic, S.M., Hardwick, L. and Dorani, F. (2011) Use of Flow Management to Mitigate Cyanobacterial Blooms in the Lower Darling River, Australia. Journal of Plankton Research, 33, 229-241. https://doi.org/10.1093/plankt/fbq094

[16] Huszar, V.L.M., Silva, L.H.S., Marinho, M., Domingos, P., Sant'Anna. C.L. (2000) Cyanoprokaryote Assemblages in Eight Productive Tropical Brazilian Waters. $\mathrm{Hy}$ drobiologia, 424, 67-77. https://doi.org/10.1023/A:1003996710416

[17] Prakash, S., Lawton, L.A. and Edwards, C. (2009) Stability of Toxigenic Microcystis Blooms. Harmful Algae, 8, 377-384. https://doi.org/10.1016/j.hal.2008.08.014

[18] World Bank (2018) The World Bank Data: Population Density (People per sq. km of Land Area)-Singapore. https://data.worldbank.org/indicator/EN.POP.DNST?locations=SG

[19] Meteorological Service Singapore (2020). http://www.weather.gov.sg/climate-climate-of-Singapore/

[20] Mowe, M.A.D. (2015) Toxic Cyanobacteria in the Tropics: Effects of Environmental Factors on the Growth and Toxin Production of Microcystis species Isolated from Singapore reservoirs. Unpublished Ph.D. Thesis, National University of Singapore, Singapore.

[21] Mowe, M.A.D, Porojan, C., Abba, F., Mitrovic, S.M., Lim, R.P., Furey, A. and Yeo, D.C.J. (2015) Rising Temperatures May Increase Growth Rates and Microcystin Production in Tropical Microcystis Species. Harmful Algae, 50, 88-98. https://doi.org/10.1016/j.hal.2015.10.011 
[22] World Health Organization (2003) Algae and Cyanobacteria in Fresh Water. Guidelines for Safe Recreational Waters, Volume 1-Coastal and Fresh Waters. WHO Publishing, Geneva, 136-158.

[23] NHMRC, NRMMC (2011) Australian Drinking Water Guidelines Paper 6 National Water Quality Management Strategy. National Health and Medical Research Council, National Resource Management Ministerial Council, Commonwealth of Australia, Canberra.

[24] PUB Singapore's National Water Agency (2020). http://www.pub.gov.sg/abcwaters/about

[25] Baird, R.B., Eaton, A.D. and Rice, E.W., Eds. (2017) Standard Methods for the Examination of Water and Wastewater. 23rd Edition, American Public Health Association, American Water Works Association, Water Environment Federation, Washington D.C.

[26] Bolch, C.J.S. and Blackburn, S.I. (1996) Isolation and Purification of Australian Isolates of the Toxic Cyanobacterium Microcystis Aeruginosa Kütz. Journal of Applied Phycology, 8, 5-13. https://doi.org/10.1007/BF02186215 


\section{Appendix}

\section{A1. Chlorophyll-a Analysis}

Water samples were filtered through $0.45 \mu \mathrm{m}$ pore size filter and $1 \mathrm{ml}$ of $1 \%$ Magnesium Carbonate $\left(\mathrm{MgCO}_{3}\right)$ solution was added to the sample before the filtration was completed. The filter paper was removed and placed in graduated centrifuge tube with $12 \mathrm{ml}$ of $90 \%$ acetone solution and shaken vigorously. The tubes were then incubated overnight at $4^{\circ} \mathrm{C}$. Prior to analysis using a spectrophotometer, the tubes were centrifuged at $3000 \mathrm{rpm}$ for 20 minutes to obtain a clear supernatant for measurement. The absorbance of the supernatant was measured at wavelengths of 750, 664, 647 and $630 \mathrm{~nm}$ with the spectrophotometer. The concentration of chlorophyll-a was calculated based on the trichromatic equation from APHA Standard Methods \#10200H [25].

\section{A2. Algal Enumeration}

$250 \mathrm{ml}$ of each water sample was aliquoted and preserved with $3 \mathrm{ml}$ of Lugol's solution. Depending on the visual appearance of algal cell density of the sample, the aliquoted sample was further diluted or concentrated. $100 \mathrm{ml}$ of the aliquoted sample was then placed in a graduated cylinder and gently inverted 10 to 20 times to ensure the sufficient mixing. $1 \mathrm{ml}$ of this sample was then counted using a calibrated Sedgewick Rafter counting chamber ensuring a minimum of 150 nos. counted for the dominant taxa. This was achieved by either counting more microscopic fields or counting more concentrated samples. Duplicate analysis would be conducted by preparing another $1 \mathrm{ml}$ of the sample). If the final counts of the duplicate sample differed by more than $25 \%$, a third sample would be counted and the final count was an average of all three sub-samples. Algae counts were expressed in cells $/ \mathrm{ml}$.

\section{A3. Cyanotoxin Analysis}

Total cyanotoxin concentration (cell bound and dissolved toxins) were analysed in the water samples. The water samples are collected and send to Health Science Authority of Singapore for analysis via Liquid Chromatography-tandem mass spectrometry (LC-MS-MS). The detection limit for all variants for Microcystin was $0.025 \mathrm{ug} / \mathrm{L}$ and $0.1 \mathrm{ug} / \mathrm{L}$ for Cylindrospermopsin and Anatoxin-a. Saxitoxin was analysed using Abraxis ELISA kits in PUB.

\section{A4. Detailed Methods for Culturing of Microcystis Strains (Table 2)}

Two species of Microcystis, M. ichthyoblabe and M. flos-aquae (LP20121219MI1, LP20121219MF1) were isolated from Lower Peirce Reservoir (LP) $\left(1^{\circ} 22^{\prime} 12^{\prime \prime N}\right.$, $103^{\circ} 49^{\prime} 33^{\prime \prime E}$ ), another strain of M. ichthyoblabe (TG20121219MI1) was isolated from Tengeh Reservoir (TG) $\left(1^{\circ} 20^{\prime} 18^{\prime \prime} \mathrm{N}, 103^{\circ} 39^{\prime} 44^{\prime \prime} \mathrm{E}\right)$, while $M$. aeruginosa (PA20130405MA) and M. viridis (UP20130405MV) were isolated from Pandan Reservoir (PA) (1 $\left.{ }^{\circ} 18^{\prime} 26^{\prime \prime} \mathrm{N}, 103^{\circ} 44^{\prime} 57^{\prime \prime E}\right)$ and Upper Peirce Reservoir (UP) $\left(1^{\circ} 22^{\prime} 12^{\prime \prime} \mathrm{N}, 103^{\circ} 48^{\prime} 17^{\prime \prime} \mathrm{E}\right)$, respectively. Cultures were maintained in the labora- 
tory using axenic techniques with nutrient rich MLA media [26] at $26^{\circ} \mathrm{C}-28^{\circ} \mathrm{C}$ under illumination with a cool white fluorescent lamp at a light intensity of 120 $\mu \mathrm{mol} \cdot \mathrm{m}^{-2} \cdot \mathrm{s}^{-1}$ on a $12 \mathrm{hr}$ light/dark cycle for $20-22$ days. Toxin analysis was carried out during mid-exponential phase for all strains. 